\title{
Radiation Sterilization Applications
}

\author{
Emine Selin Demir (Corresponding author) \\ Department of Radiopharmacy, Faculty of Pharmacy, \\ Ege University, Bornova, Izmir, Turkey \\ E-mail: emine.selin94@gmail.com \\ Emre Ozgenc \\ Department of Radiopharmacy, Faculty of Pharmacy, \\ Ege University, Bornova, Izmir, Turkey \\ E-mail: emreozgenc90@gmail.com \\ Evren Atlihan Gundogdu \\ Department of Radiopharmacy, Faculty of Pharmacy, \\ Ege University, Bornova, Izmir, Turkey \\ E-mail: evren.atlihan@gmail.com
}

\begin{abstract}
Sterile products are used in many fields and sterile service is provided nowadays. The use of sterile products in medical equipment, pharmaceuticals, pharmaceutical and active substance combinations, animal husbandry, cosmetics and perfumery, packaging and food sectors is very important. The radiation sterilization is becoming widespread thanks to developing technology and industrial activities and can be used for sterilization of many materials especially raw materials. The use of gamma ray and accelerated electrons in radiation sterilization is common. The selection of sterilization method is crucial for appropriate products. Herein, we mentioned that sterilization, sterilization method, advantages of radiation sterilization techniques and other sterilization methods.
\end{abstract}

Keywords: Radiation, Sterilization, Radiation sterilization

DOI: $10.7176 / \mathrm{JSTR} / 5-12-13$

\section{Radiation \\ 1.1 Radiation and Radioactivity}

Atoms have electrons, protons and neutrons. At this point, atoms which proton number is equal to the electron number call electrically uncharged and stable. In addition to stable nuclides, there are many unstable nuclides. Stability can be interpreted according to the balance between the proton and neutron. Small stable nuclides have an equal number of protons and neutrons. In big nuclides, there is difference between proton and neutron numbers. Some nuclides tend to convert a neutron into a proton, leading to a more stable structure. This process, also known as beta decay, results in the release of a negatively charged electron (beta minus particle). Some nuclides convert excess protons into neutrons. They lose their positive charge by positron emission (beta plus particle). The spontaneous conversion of the nucleus from the unstable to the stable state due to the energy it possesses is called radioactivity or radioactive fragmentation. Radiation is also the transfer of energy through particles or electromagnetic waves. The action of the transformation of atoms from the unstable to the stable state is known radioactive decay (TAEK 2009).

Some parameters are effective in the classification of radiation. The most used of these parameters is the energy and source of radiation. Radiation is divided into groups:

- Ionize radiation: This group has high-energy radiation and capable of removing an electron from an atom of the substance. Examples of this group include alpha, beta and neutron (particle type radiation), high-energy ultraviolet, gamma rays and $\mathrm{x}$-rays.

- Non-ionize radiation: It has low-energy radiation that cannot remove electrons from an atom of 
the substance. Microwaves in the electromagnetic spectrum, visible light, infrared and low energy ultraviolet light are examples of non-ionize radiation (TAEK, 2016; Çimen et al., 2017)

\subsection{Radiation Types}

Alpha radiation $(\alpha)$ is emitted by a large unstable atomic nucleus. Because of the instability of the nucleus and excess of both protons and neutrons, the nucleus emits an alpha particle consisting of two protons and two neutrons (Positively charged helium core).

$$
{ }_{88}^{222} \mathrm{Ra} \rightarrow{ }_{2}^{4} \mathrm{He}+{ }_{86}^{218} \mathrm{Rn}
$$

The alpha particle is a heavy particle, although it causes high radiation exposure, and therefore has a short range in the air (1-2 cm only). They do not pose an external radiation hazard and can be stopped with a piece of paper.

While Beta radiation $(\beta)$ can be an electron and has negative charged by an unstable atomic nucleus, and $'+\mathrm{p}$ charged by a positron. Beta particles are much smaller than alpha particles. So it can penetrate further into the tissues or materials. It can be completely absorbed by plastic, glass and metal layers. It cannot go beyond the top layer of the skin. However, high-energy beta emitters can cause excessive skin irradiation because of excessive irradiation.

The source of gamma radiation $(\gamma)$ is the nucleus of the atom. The atomic nucleus emits its excess energy as gamma rays to stabilize after the alpha or beta particle is released. It is different from alpha and beta radiation when compare to electromagnetic radiation. As matter passes through it, it interacts with electrons and causes ionization in atoms. It is very intrusive, so good shielding can only be achieved with high-density thick materials such as lead, steel or concrete. When ingested or inhaled, the body gives a serious use of radiation to the internal organs. They most commonly used in industry and medicine.

$X$-rays are high-energy photons and similar to gamma radiation. They are produce by slowing down an electron beam very quickly and have high penetration. They ionize the substance to form biological and chemical damages. and are stopped with dense materials such as lead and concrete.

Neutron radiation $(n)$ is a neutron emitted from an unstable atomic nucleus and produced by fission, fusion, particle interactions (particle accelerators) or cosmic rays. They do not cause direct ionization. Because they are very intrinsic, they may cause alpha, beta, gamma or x-rays, which cause ionization when they interact with the substance or tissue.

Cosmic radiation is a mixture of many different types of radiation, including protons, alpha particles, electrons, and other high energy particles from the depths of space. (TAEK, 2009; TAEK 2016)

\subsection{Radiation Sources}

There are two main sources of natural and artificial radiation. Natural radiation is spontaneous radiation in nature without any human contribution. Cosmic rays coming from space, gamma rays emitted by short-lived radioisotopes in the earth, radioactive elements in our body and radon gas emitted as a result of decay of radium are natural sources of radiation (Hizarci, 2018).

Some sources of radiation are not available in nature and can also be produced by artificial materials. These are called artificial sources of radiation. They are used in many areas likewise medical X-rays, atmospheric fallout from nuclear weapons trials, emission of nuclear industry radioactive waste, industrial gamma and X-rays and other consumer products (TAEK 2009).

\section{Sterilization}

Sterilization is the killing or removal of all living and active forms of all microorganisms in a product. It can also be prepare the non-microorganism environment. At the end of the sterilization application, the product should not contain any living organisms, including bacterial spores (Ozer and Ozyazici 2015). Sterilization, which is a process of purification from viable organisms, is terminal sterilization if it is carried out as a finished product in its own container (Ozer and Ozyazici 2015; Ozkırım Ustundag 2009). In some cases, aseptic technique is used to prevent the product content from being adversely affected. This method is known non-terminal sterilization.

The effectiveness degree of sterilization is defined by the word 'sterility'. Sterility is mainly expressed by the sterility assurance level (SAL) levels of the products or the materials exposed to sterilization and may take different values depending on the intended use of the product (Ozkırım Ustundag 2009). The probability of a non-sterile substance in a population is indicated by SAL. The SAL of a sterilization process is the degree of guarantee of the sterilization process that makes substances in a group of 
substances sterile (Ozer and Ozyazici 2015). This limit is considered $10^{-6}$ in pharmacopeias (Gunaydın et al. 2015). The important thing is to calculate the conditions which this limit is reached and time. For this calculation, it is necessary to know the initial concentration of microorganisms in the material and the resistance of the microorganisms and spores to the applied method (eg temperature or radiation). D, $\mathrm{Z}$ and $\mathrm{F}$ values are used in the calculations to be made to know these criteria. The calculations of $\mathrm{D}, \mathrm{Z}$ and F parameters are shown in Table 1 (Ozer and Ozyazici 2015).

Table 1. The lethality curves used in the evaluation of sterilization

\begin{tabular}{|l|l|l|l|l|}
\hline Name of curve & Type of curve & Ordinate & Absis & Slope \\
\hline Live survivors & Semi log & Log N & Time & D value \\
\hline Resistance & Semi log & Log D & $\begin{array}{l}\text { Temperature, } \\
\text { dose, } \\
\text { concentration }\end{array}$ & Z value \\
\hline $\begin{array}{l}\text { Temperature } \\
\text { versus death time }\end{array}$ & Linear & $10 * \mathrm{~T}-\mathrm{To} / \mathrm{Z}$ & Time & $\begin{array}{l}\text { F value under- } \\
\text { curve area }\end{array}$ \\
\hline
\end{tabular}

\subsection{Sterilization Methods}

Sterilization methods are classified under three main headings as physical, chemical and aseptic techniques.

\section{A. Physical sterilization methods}

Sterilization methods using temperature

- Dry heat sterilization

- Saturated steam (saturated steam) sterilization (wet heat sterilization)

Sterilization methods where temperature is not applied:

- Radiation sterilization

- Sterilization by filtration

\section{B. Chemical sterilization methods}

Gas sterilization:

- Sterilization with ethylene oxide (EtO) gas

C. Aseptic method (Tirnaksiz 2009)

In the light of these headings, there are 5 basic sterilization methods which are valid in pharmacopeias and have different characteristics.

- Sterilization with Humid Hot Air

- Dry Hot Air Sterilization

- Sterilization with Gases

- Sterilization by Filtration

- Radiation Sterilization

\section{Radiation Sterilization}

Radiation sterilization is a terminal sterilization method and carried out with controlled levels of rays, does not need heat. Also products can be sterilized in their packages with this method. In principle, ionized radiation is used (Tirnaksız 2009). The first use of ionizing radiation in this field took place in 1895 and was patented in 1921 (Ozkırım Ustundag 2009). In the 1950s, USA, France and UK began to apply the first irradiation plant that was established in 1956 in Australia for the sterilization of sheep wool (Alkan 2018). Since 1994, more than 200 gamma irradiation institutes and around 1000 electron beam accelerators have been installed in 50 countries. The use of radiation sterilization has increased by 10-15\% when compared to the previous year (Silindir and Özer 2009). In Turkey, 2 gamma irradiation facilities were serve radiation sterilization service. Turkey Atomic Energy Agency (TAEK) was established with the support of irradiation technology and had Co-60 Gamma Irradiation Facility. Gamma Sterilization-Pak Inc. is a commercial Co-60 Gamma Irradiation Facility established in ÇerkezköyTekirdağ (Alkan 2003).

The radiation level is controlled by adjusting the exposure time to the product. The product with the desired microbiological level and minimum damage to product the is defined radiation dose. The radiation dose depends on the number of radiation-sensitive microorganisms in the product, the desired SAL value and the manufacturing conditions of the product. In pharmacopeias, $25 \mathrm{kGy}$ is accepted as the sterilization dose. This dose provides $10^{-6}$ of SAL value. 
Irradiation has two effects which are direct and indirect on the cell. The interaction between radiation beam and vital DNA is the sample of direct effect. As a result of damage to the genetic material, cell proliferation is prevented, vital activities stop and microorganism is inactivated. The effect of free radicals on the material by the interaction of radiation damage to the genetic material (water molecules) in indirect effect. Hydrogen peroxide, $\mathrm{OH}^{-}, \mathrm{H}^{+}$and $\mathrm{e}_{\text {aq }}^{-}$radicals and genetic material and the basic vital molecules as a result of reactions between the cell is inactivated (Ozer and Ozyazici 2015).

The radiation classification allows us to better understand the types of radiation used in sterilization. Ionized and non-ionized radiations are used in radiation sterilization. Gamma and accelerated electrons are preferred for ionized radiation sterilization. UV rays are another source of non-ionized radiation sterilization.

Ionizing radiation used for sterilization purposes is examined in two groups as electromagnetic and particle borne radiation. Gamma rays and UV rays are used for sterilization in electromagnetic radiation. In the radiation of particles, accelerated electrons are commonly used (Ozkırım Ustundag 2009).

\subsection{Sterilization with Gamma Radiation}

The gamma radiation process is the exposure of the product to controlled levels of ionizing gamma radiation. Cobalt-60 $\left({ }^{60} \mathrm{Co}, \mathrm{Co}-60\right)$ gamma rays are used in this sterilization. Two protons and one electron are emitted from the Co-60, corresponding to a total energy of $2.81 \mathrm{MeV}$. Cesium-137 $\left({ }^{137} \mathrm{Cs}\right.$, Cs-137) is also used in gamma sterilization. It is preferred for sterilization of blood and blood products. The energy level of the beam emitted is lower than cobalt $(0.66 \mathrm{MeV})$. So it is not preferred too much. Gamma rays are formed by the self-breakdown of Co-60 or Cs-137, they are short wavelength, high energy and have high penetration power (Ozer and Ozyazici 2015). The gamma irradiation facility consists of 3 main parts: the cell where the irradiation source is located, the product carrier conveyor and the storage area.

Co-60 welders used in gamma irradiation devices which consist of a large number of Co- 60 pens filled into rods, but are enclosed in two layers of stainless steel capsules to protect them from external influences and to prevent leakage. The products are filled into irradiation boxes in their original packaging and carrier cartons or placed on pallets properly and transported to the irradiation cell by a conveyor (Figure 1). With the high energy and intrinsic properties of gamma rays, the predicted treatment dose is given to the products by penetrating into the products with high density. The irradiation boxes are alternately irradiated from two different directions to ensure a uniform dose distribution throughout the products. The gamma energy will be exposed directly to products in the irradiation cell (Taner 2018). It is a cold sterilization method that allows the products to be processed in their original packaging and transport boxes. Gamma rays penetrate all over the product and leave no residue on the product. It does not require quarantine time (Ozkirim Ustundag 2009).

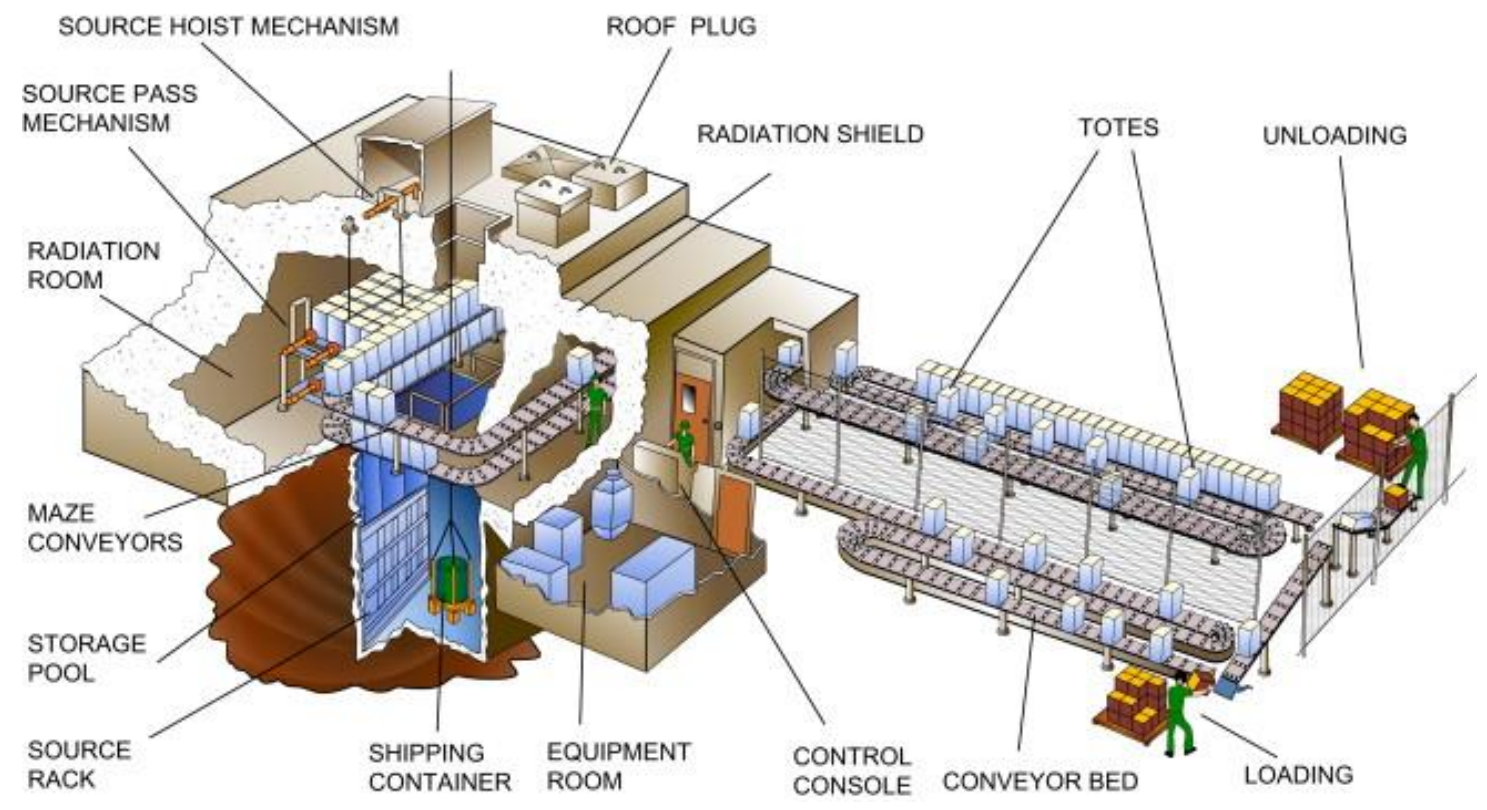

Figure 1. High volume production gamma irradiation facility (Lambert and Martin 2013) 
Gamma radiation is applied to disposable medical products, health care products, pharmaceuticals, pharmaceutical raw materials, pharmaceutical containers, cosmetic and cosmetic raw materials. Also they used in all areas of health product such as surgical instruments, needles, dialysis sets, implants, petri boxes, test tubes, blood donation sets, gauzes, galoshes, air filters, tongue sticks, heart valves. Drugs in tablet form, herbal medicines, injectable antibiotics, antibacterials, steroids, alkaloids generally in dry, powder, crystalline and lyophilized form, eye and skin ointments, veterinary medicines, dry form vitamins, aerosols, liposomal for injection, nanospheric, microspheric controlled drug delivery systems, cosmetic gelatin, starch, kaolin, talc, ear piercing kits, bandages, disposable teats, tampons, essential oils and eye and lip creams (Ozer and Ozyazici 2015; Izgü 1983; Tırnaksız 2009).

Gamma sterilization is a highly preferred method because it provides high penetration to the product, leaves no residue in the product, it applies to the end product and it is a cold method (Ozkirim Ustundag 2009). In addition to these advantages, the radioisotope is difficult to find and has high cost, irradiation cannot be interrupted at any time, such as disadvantages (Ozer and Ozyazici 2015).

\subsection{Sterilization Using Accelerated Electrons}

Although gamma radiation sterilization has been used for many years, sterilization using accelerated electrons (electron beam, e-beam) is a new method. It requires an electron accelerator and is performed by the use of electron beams formed in the accelerator. The energy of the electrons produced and accelerated is increased by specially designed machines. In the irradiation system with accelerated electrons, electrons are concentrated and accelerated in a manner similar to the speed of light. An on-off technology that uses electrical energy is used. This is a continuous process. The electrons emitted from the instrument increase to an energy level of 3-15 million electron volts $(\mathrm{MeV})$. They cause very rapid reactions to the microorganisms in the sterilized product (Silindir and Ozer 2009). The high energy of the electrons ensures that the decreasing of sterilization time. The e-ray method has recently attention due to its safety for sterilization of medical devices. It is the most efficient technology for low-density medical devices packed in boxes. It is more preferable to gamma sterilization for box packages and low density devices.

\subsection{Sterilization with Ultraviolet (UV) Rays}

Sterilization performs with UV rays in this method. The greatest antimicrobial effect of UV radiation is in the wavelength range of $250-260 \mathrm{~nm}$. The beam at the wavelength of $2537 \mathrm{~A}^{\circ}(253.7 \mathrm{~nm})$ is the most effective for UV spectrum and is well absorbed by the DNA in the cells. Chemical covalent bonds are formed between the absorbed energy and adjacent thymine bases and thymine dimers are formed. The obtaining thymine dimers are the main mechanism of cellular UV damage. The effect of UV light depends on the resistance of microorganisms to light, the type of microorganism, the number, the state of the microorganism, the stage of the life cycle, the presence of organic structures in the environment, the wavelength of the light . Bacterial spores are known to be much more resistant to UV radiation (about 3 10 times). Viruses also die under UV light and their resistance is less than that of bacterial spores. The UV radiation sterilization is provided by UV lamps. More than $90 \%$ of the UV light is emitted by mercury vapor lamps consists of light with a wavelength of $253.7 \mathrm{~nm}$ (Tirnaksiz 2009).

UV radiation is low in energy and poor in penetration power. Therefore, their use is limited as they cannot provide absolute sterilization. UV rays pass easily through dust-free air and clean water. However, ordinary glass, dirt and oil layers, cloudy solutions, such as milk and plastic materials cannot effectively pass. The important thing is that UV rays come directly to organisms and mainly used for sterilizing air, water and smooth surfaces such as wrapping paper (Ozkirim Ustundag 2009).

In the light of all sterilization methods, the advantages of radiation sterilization are summarized as;

- Easy, reliable and economical.

- Provides sterilization in final packaging.

- It has an effective intrusion feature.

- It causes the sample temperature to increase slightly.

- Validation is easy (dosimetric).

- It is a guaranteed process, providing quarantined product delivery.

- Does not harm the environment.

- Provides batch or continuous type sterilization. 
- Can be controlled by one parameter (time).

- Leaves no chemical residue, no risk of poisoning or cancer.

- Provides application to a wide range of materials and packaging.

- Employee safety is at the highest level in accordance with the rules adopted (Ozer and Ozyazic1 2015).

\section{Conclusion}

It is important to choose the available method in the sterilization process. At this point, the properties of the product to be sterilized should be well known; physical chemistry, the number of microorganisms, moisture content, $\mathrm{pH}$ value, microorganism sensitivity and the amount of organic structure in the environment should be investigated. The most appropriate method for sterilization of the product should ensure effective sterilization and should not lead to microscopic changes in the product. At this point, technological advances have shown that radiation can also be used in sterilization processes. Compatibility with a wide range of materials, fast, reliable and guaranteed process increases radiation sterilization applications.

\section{References}

Alhan, H., 2003. Türkiye' de Endüstriyel Gama Işınlamasi Uygulamaları. 3. Sterilizasyon ve Dezenfeksiyon Kongresi, Ekim, SAMSUN.

Alkan, H., Radyasyonla Sterilizasyon ve Biyolojik Yük Kontrolü, Gamma-Pak Sterilizasyon San. Ve Tic. A.Ş. Date of access : February 2018 [Available from: http://www.ikev.org/haber/2002validpdf/Sunum\%20Alkan.pdf]

Cimen, B., Erdogan, M., Ogul, R., 2017 İyonlaştırıcı radyasyon ve korunma yöntemleri. Selçuk Üniversitesi Fen Fakültesi Fen Dergisi. 43(2):139-147.

Gunaydın, M., Perçin, D., Esen, Ş., Zenciroğlu, D., 2015. Sterilizasyon Dezenfeksiyon Rehberi. İstanbul: Artvin Yayınevi; 12:73-83.

Hızarc1, S. Radyasyon kaynakları ve Radyasyondan Korunma, Türkiye Atom Enerjisi Kurumu Türkiye Kurumu Radyasyon Sağlığı ve Güvenliği Dairesi Radyasyon Dairesi. [Date of access: 8 Şubat $2018 \quad$ Available

from: http://www.cygm.gov.tr/cygm/files/guncelbelgeler/radyasyon_olcum_sunum.pdr]

Izgu, E., 1983. Genel ve Endüstriyel Farmasötik Teknoloji II. Ankara: Ankara Üniversitesi Eczacılık Fakültesi Yayınlar1; 95-119.

Jongen, Y.,1998. Review of compact commercial accelerator products and applications. Ion Beam Applications, Louvain - la - Neuve, Belgium, 3770-3774.

Lambert, B., Martin, J., 2013. Sterilization of Implants and Devices, Biomaterials Science, An Introduction to Materials in Medicine. Third Edition, 1339-1353

Ozkırım Ustundag, I., 2009. Radyasyonla sterilizasyon işlemi sırasında kozmetik ürünlerde ve ürün hammaddelerinde oluşan radikalik arabirimlerin karakterizasyonu doktora tezi. Hacettepe Üniversitesi, 6-14.

Ozer, O., Ozyazıcı, M., editors. 2015. Farmasötik Teknoloji III. İzmir: Ege Üniversitesi Yayınları; 81106.

Silindir, M., Ozer, A.Y., 2009. Sterilization methods and the comparison of e-beam sterilization with gamma radiation sterilization. FABAD Journal of Pharmaceutical Sciences. 34(1):43-53.

Türkiye Atom Enerjisi Kurumu Komisyonu. Radyasyon, İnsan ve Çevre. ISBN: 978-975-8898-28-2 Ankara: TAEK 2009;1-14).

TAEK Kurs Sunumlar1. [Available from: http://www.taek.gov.tr/tr/belgeler-formlar/KursSunumlar\%C4\%B1/ERRK/1_RADYASYONLA-\%C4\%B0LG\%C4\%B0L\%C4\%B0KAVRAMLAR/lang,tr-tr/] 
Taner, C.A. Yeni kuşak radyasyon teknolojileri uygulamaları ve Kobalt-60 (Co-60) gama ışınlama tesisleri. Ankara: Türkiye Atom Enerjisi Kurumu [Date of access: 23 Şubat 2018, Available from: http://www.fmo.org.tr/wp-content/belgeler/yenikusakguc.pdf]

Tırnaksız, F., 2009. Sterilizasyon. Modern Farmasötik Teknoloji 2. baskı. Ankara: Mattek Basımevi, S.63-88. 